\title{
Biological control with essential oil of Foeniculum vulgare Mill
}

\author{
Djamila Hamada $^{1 *}$, Roumeissa Bekri ${ }^{2}$, Aicha Medjahid ${ }^{2}$, Romaissa Kamaci ${ }^{3}$, Hakim Belkhalfa ${ }^{4}$, Nasrine \\ Salhi $^{3}$, Segni Ladjel ${ }^{1}$ \\ ${ }^{1}$ Ouargla University, Faculty of Applied Sciences, Laboratory of Process Engineering, Ouargla, Algeria, (ORCID: 0000-0002-9681-7810), saouddjamila8@ gmail.com, \\ (ORCID: 0000-0002-6016-9428) \\ ${ }^{2}$ Ouargla University, Mathematic and Matter sciences, Departmant of chemistry, Ouargla, Algeria. (ORCID: 0000-0003-4141-1335) roumeissabekri98@ gmail.com, \\ (ORCID: 0000-0002-8667-3438) amoudjahed@yahoo.com \\ ${ }^{3}$ Ouargla University, Faculty of Nature Sciences and life, Laboratory of Saharan Bioresources Preservation and Recovery. Ouargla, Algeria. (ORCID: 0000-0003-0082- \\ 9874) \\ ${ }^{4}$ Center for Scientific and Technical Research in Physicochemical Analysis (C.R.A.P.C), Ouargla, Algeria. (ORCID: 0000-0001-9992-346X)
}

(1st International Conference on Applied Engineering and Natural Sciences ICAENS 2021, November 1-3, 2021)

(DOI: $10.31590 /$ ejosat.981759)

ATIF/REFERENCE: Hamada, D., Bekri, R., Medjahid, A.,Kamaci, R., Belkhalfa, H., Salhi, N., \& Ladjel, S. (2021). Biological control with essential oil of Foeniculum vulgare Mill. European Journal of Science and Technology, (28), 52-55.

\begin{abstract}
The present study was aimed to investigate, the chemical composition of the essential oil extracted by hydrodistillation from Fennel (Foeniculum vulgare Mill.) harvested in South-Est, Algeria, and to evaluate its antifungal and allelopathic activities.

Gas chromatography-mass spectrometry GC-MS analysis of $F$. vulgare essential oil showed the presence of 11 components, alpha.phellandrene (29.44\%) was found as the main component. The essential oil was tested on the seeds of 2 crops (Chenopodium quinoa Willd.) Variety Q102 and (Triticum durum Desf.) variety vitron, The final germination percentages and the seedling shoot and root lengths were significantly reduced by the $F$. vulgare essential oil as compared to the control. Furthermore, the antifungal study on the fungi of Aspergillus niger and Aspergillus flavus reported significant results. The effectiveness of the oil showed that it has a fungicidal effect against the two strains. These findings suggest that the $F$. vulgare essential oil can be used as a source of environmental-friendly in bilogical control.
\end{abstract}

Keywords: Allelopathie, Antifungal activity, Foeniculum vulgare Mill., Essential oil.

\section{Foeniculum Vulgare Mill'in Uçucu Yağı İle Biyolojik Kontrol}

Öz

$\mathrm{Bu}$ çalışmanın amacı, Cezayir'in Güney-Doğu bölgesinde hasat edilen Rezene'den (Foeniculum vulgare Mill.) hidrodistilasyon yoluyla elde edilen uçucu yağın kimyasal bileşimini araştırmak ve antifungal ve allelopatik aktivitelerini değerlendirmektir.

Gaz kromatografisi-kütle spektrometrisi F. vulgare uçucu yağının GC-MS analizi, 11 bileşenin varlığını göstermiş ve alfa.phellandrene (\%29.44) ana bileşen olarak bulunmuştur. Uçucu yağ, 2 mahsulün (Chenopodium quinoa Willd.) Çeşit Q102 ve (Triticum durum Desf.) çeşidinin vitron tohumları üzerinde test edilmiştir. Kontrol amaçlı karşılaştırıldığında F. vulgare esansiyel yağı ile nihai çimlenme yüzdeleri ve fide sürgün ve kök uzunlukları önemli ölçüde azaltılmıştır. Ayrıca, Aspergillus niger ve Aspergillus flavus mantarları üzerinde yapılan antifungal çalışma önemli sonuçlar bildirmiştir. Yağın etkinliği, iki suşa karşı mantar öldürücü bir etkiye sahip olduğunu göstermiştir. Bu bulgular, F. vulgare esansiyel yağının biyolojik mücadelede çevre dostu bir kaynak olarak kullanılabileceğini düşündürmektedir.

Anahtar Kelimeler: Allelopathie, Antifungal aktivite, Foeniculum vulgare Mill., Uçucu yağ.

\footnotetext{
* Corresponding Author: saouddjamila8@gmail.com
} 


\section{Introduction}

The use of herbicides has a harmful effect on the environment and public health. Accordingly it is important to alternatives for controlling weeds. An alternative suggested by the author, to control weeds, is the development and application of control measures with plant products (Alves et al., 2014). Many plants synthesize toxic substances for defense against other plants and microorganisms including viruses, bacteria, and fungi. (Liman et al., 2012, Kucukboyac et al. 2011) Allelopathy is a biological phenomenon by which an organism produces one or more biochemicals that influence the growth, survival, and reproduction of other organisms (El Ayeb et al., 2014).

The lamiaceae family is one of the most widely used families as a global source of spices and extracts with strong antimicrobial and antioxidant properties. (Goudjil et al., 2020) Fennel is a member of the family Apiaceae. It is classified into two sub species: subsp. Capillaceum which includes three varieties (azoricurm Miller, dulce Miller (sweet fennel) and vulgare), Subsp. Piperitum (pepper fennel)., (Muckensturm et al., 1997; Marotti et al., 1994; Piccaglia and Marotti, 2001).

The plant and its essential oil have been extensively used as carminative, digestive, galactogogue and diuretic and to treat respiratory and gastrointestinal disorders (Farukh et al., 2017). It is also used as a constituent in cosmetic and pharmaceutical products, the plant and its essential oil have been extensively used as carminative, digestive, galactogogue and diuretic and to treat respiratory and gastrointestinal disorders ( Mimica-Dukic et al., 2003). It is also used as a constituent in cosmetic and pharmaceutical.

\section{Material and Method}

\subsection{Plant material}

The aerial parts of Wild fennel $F$. vulgare harvested in February 2021 in the region of Elmarmouthia (South-East Algeria) then dried in the shade at an ambient temperature during 10 days then hydrodistilled using a Clevenger-type apparatus for $3 \mathrm{~h}$ to give an essential oil yield of $0.89 \%$.

\subsection{Gas chromatography-mass spectrometry analysis}

The analysis of $F$. vulgare EO was performed at the scientific and technical research center in physico-chemical analyzes (CRAPC).. The apparatus used is a gas chromatograph of the (TQ $8040 \mathrm{NX}$ ) type coupled with a mass spectrometer. quadrupole ionization voltage of $70 \mathrm{ev}$. The column that is used is an HP-5MS; 5\% Phenyl Methyl Siloxane with a length of 30 $\mathrm{m}$ and an internal diameter of $0.25 \mathrm{~mm}$. The wire thickness being $0.25 \mathrm{~mm}$. The operating conditions are:

- The temperature of the injector (split mode 1:20): $250{ }^{\circ} \mathrm{C}$

- Temperature programming: from $70{ }^{\circ} \mathrm{C}$ to $280{ }^{\circ} \mathrm{C}$ at a rate of

$4{ }^{\circ} \mathrm{C} / \mathrm{min}$.
- The vector gas used is helium with a flow rate of $0.79 \mathrm{ml} / \mathrm{min}$. The temperatures of the quadrupole source are fixed, respectively, at $250{ }^{\circ} \mathrm{C}$ and $280^{\circ} \mathrm{C}$. Linear retention indices (RI) for all compounds were determined using n-alkanes as standards. Identification of individual compounds was performed by matching their mass spectral fragmentation patterns with corresponding data available (Wiley 275 library (6th edition))..

\subsection{Allelopathic activity}

Each concentration was prepared with diluted F. vulgare EO in DMSO then added sterile distilled water to give final concentrations of : $0.5 ; 1 ; 2: 3 \%$. All germination tests are performed in sterile glass Petri dishes with a diameter of $90 \mathrm{~mm}$ and a height of $18 \mathrm{~mm}$. Standard filter discs equal to the diameter of the plates are placed in Petri dishes. After we put 25 quinoa seeds in a Petri dish and 10 wheat seeds in another one. Then pour a few milliliters (enough to cover only the seeds) of each cencentration in each Petri dish and for each concentration, we kept three replicates. Germination is indicated by taking out the roots from the seed layer at least $2 \mathrm{~mm}$ long. The germination rate corresponds to the maximum percentage of germinated seeds compared to the total seeds sown, it estimated by the following formula (Alves et al., 2014):

$\mathbf{G P} \%=(\mathrm{NI} / \mathrm{NT}) \times \mathbf{1 0 0}$

Where GP: germination percentage (\%).

NI: The number of seeds germinated.

NT: The total number of seeds sown.

The inhibitory or stimulatory percent was calculated using the following equation given by Chung et al., 2001:

inhibition $(-) /$ stimulation $(+) \%=[($ extract - control $) /$ control $]$ $\times 100$,

where 'extract' is the parameter measured in the presence of the $F$. vulgare EO and 'control' is the parameter measured in the presence of distilled water.

\subsection{Anti-fungal activity}

The antifungal activity was to examine the chemical composition of the essential oil extracted from the F. Vulgare against two species: Aspergillus niger and Aspergillus flavus prepared in the biology laboratory of the University of Ouargla.

The method used according to goudjil et al., with slight modifications. Is the direct contact method where the 04 concentrations in which concentration is obtained by adding of essential oil to $30 \mathrm{ml}$ lukewarm Potatoes Dextrose Agar PDA in a bottle plus $0.5 \%$ DMSO. After shaking the flasks, the medium is poured into plastic dishes $90 \mathrm{~mm}$ in diameter. The inoculation is done under the Biological safety cabinets by depositing in the center of the dish a disc of the mycelial about $6 \mathrm{~mm}$ in diameter. Petrie dish containing $15 \mathrm{ml}$ of PDA medium plus DMSO and the other only PDA, both without oil essential are inoculated to serve as a control. The Petri dishes (controls and tests) are incubated at $25 \pm 2{ }^{\circ} \mathrm{C}$ respectively for 7 days. All tests, are restarted three times (Goudjil et al., 2020). 
Table 1. Chemical coposition of Algerian F. Vulgare EO

\begin{tabular}{|c|c|c|}
\hline Copounds & Retention time (min) & Area $(\%)$ \\
\hline$\beta$-Pinene & 4.17 & 0.6 \\
\hline alpha.-phellandrene & 4.39 & 29.44 \\
\hline o-Cymene & 4.53 & 10.11 \\
\hline D-Limonene & 4.58 & 19.48 \\
\hline Sabinene & 4.61 & / \\
\hline$\alpha$-Terpinolene & 5.11 & 0.22 \\
\hline Dill ether & 6.10 & 21.52 \\
\hline (E)-Pinocarveol & 6.27 & 0.34 \\
\hline trans-Sabinol & 6.65 & 0.14 \\
\hline (-)-Carvone & 6.74 & 9.76 \\
\hline Durenol & 7.36 & 2.18 \\
\hline
\end{tabular}

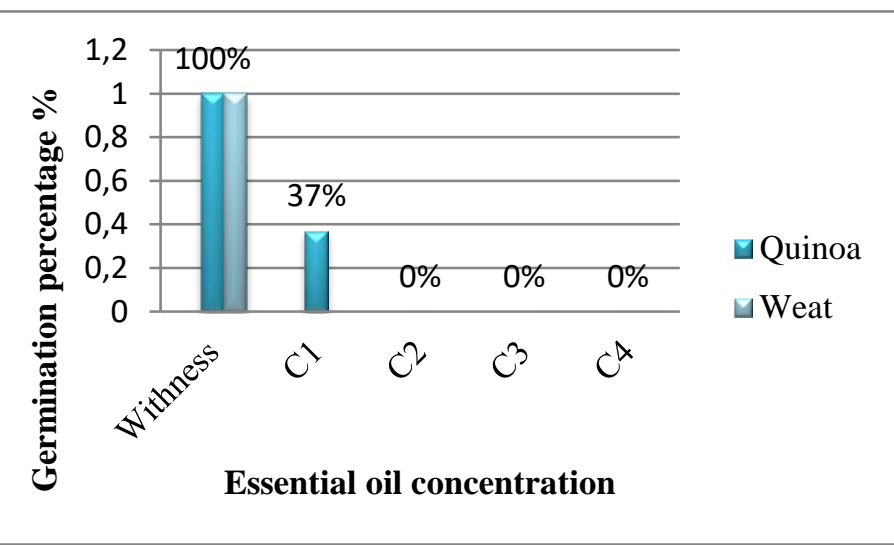

Figure 1. Germination percentage of Wheat and quinoa seeds treated with F.vulgare oil

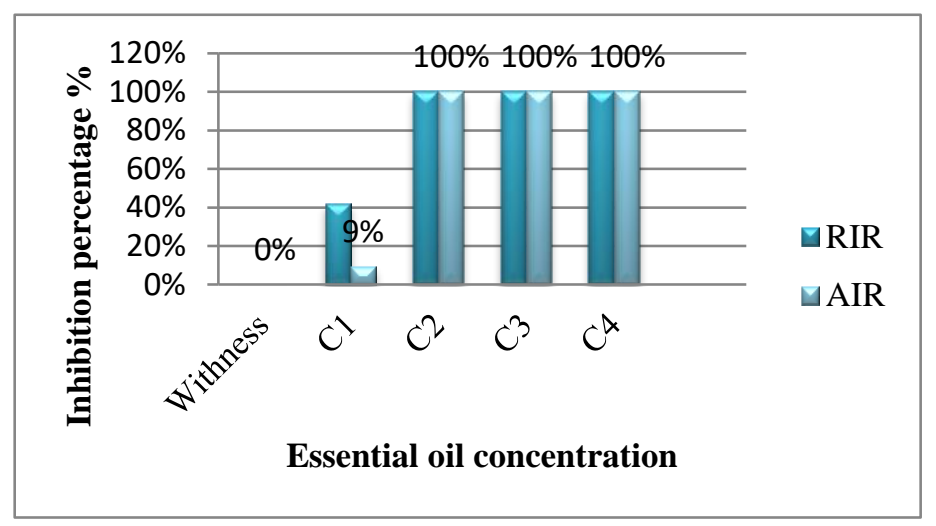

Figure 3. Inhibition of RIR and AIR recorded for Quinoa seeds treated with $F$. vulgare oil

\section{Results and Discussion}

\subsection{Chemical composition of essential oil}

Analysis of the spectral data of the compounds detected 11 copounds with those of the standards cited in the databases, Nist and Willy (Table 1), whose alpha.-phellandrene (29.44), Dill ether (21.52) and D-Limonene (19.47), (-)-carvone (9.76) respectively are regarded major components.

Rahmani (1986) has reported that wild fennel seeds essential oil from the Azrou region (Middle Atlas, Morocco) were rich in hydrocarbon monoterpenes with a predominance of a-phellandrene (39\%), limonene $(21.4 \%)$ and a-pinene $(17.6 \%)$.While, Shahat et al. (2012), has reported that the wild plants showed much higher level of limonene $(84.49 \%)$. These variations may be related to the combined effect of many agents

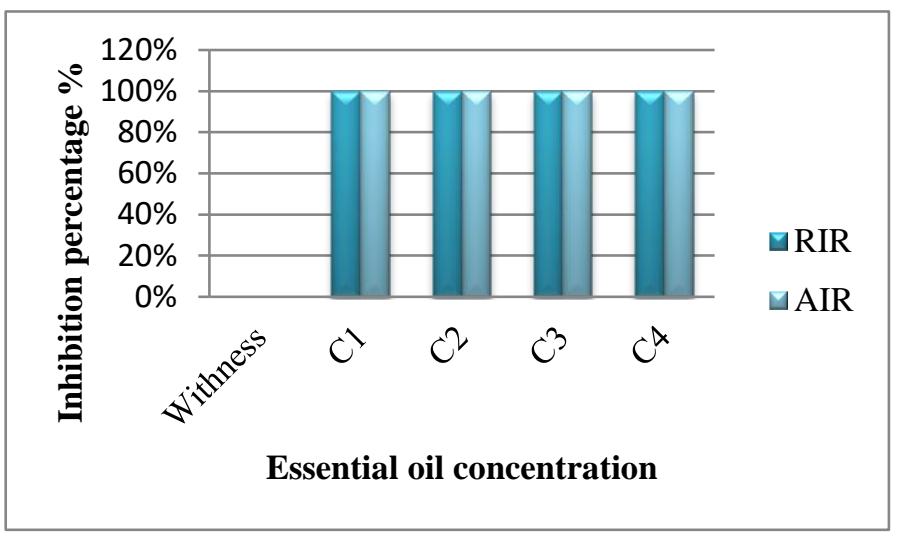

Figure 2. Inhibition of RIR and AIR recorded for Wheat seeds treated with F.vulgare oil.

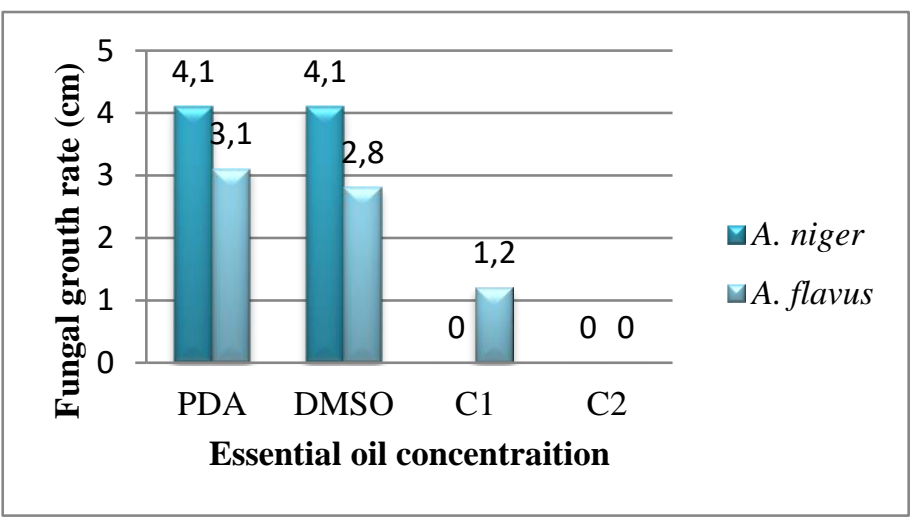

Figure 4. Mycelial diameter grouth under the effect of $F$. vulgare oil

comprising genetic factors and geographic origin as reported by several studies (Bahmani et al., 2015; Gholami Zali et al., 2018 ; Mustapha et al., 2020).

\subsection{Allelopathic activity}

The effect of essential oil concentrations on the final seed germination rate of the species tested which are shown in (figure1). We note that the percentage of inhibition of the aerial part is higher than the percentage of root inhibition for quinoa seeds at (C1) and it increases with increasing of concentration of the essetial oil. The inhibitory effect is total for wheat seeds with different concentrations (figure 2, figure 3 ). These tests proved that our essential oil has an inhibitory effect on the 2 seeds germination tested; with relatively high inhibition rates.

In Previous studies basic research on the allelopathic potential of fennel (Foeniculum vulgare) seed at several 
concentrations showed that this medicinal plant exhibited a significant inhibitory effect on the seed germination and seedling lengths of all examined weeds (maryam et al., 2011). (Gilani et al. 2010) also reported that $F$. vulgare is one of the top 10 medicinal plants with the highest inhibitory effect against the germination of lettuce (Lactuca sativa L.) seeds .

\subsection{Anti-fungal activity}

The activity of different concentrations of essential oil of fennel on different fungal strains tested is revealed by the absence or presence of mycelial growth (figure 4).

According to (figure 4), it is observed that the inhibition rate has a fungicidal effect for the two fungal strains. It is increased with the increase of EO concentration.

Previous studies also found that fennel essential oils possessed an inhibitory effect against awide range of fungi (Anwar et al., 2009, Singh et al., 2003 ), which supported our results in the present study, indicating that essential oil of fennel was a potent fungal inhibitor.

\section{Conclusions and Recommendations}

This study has been devoted to determine the essential oil coposition ant to evaluate allelopathic and anti fungal activities. analysis of the F.vulgare essential oil made it possible to identify 11 constituents, F. vulgare EO is dominated by alpha.phellandrene, Dill ether, D-Limonene and (-)-carvone.

F.vulgare essential oi exhibited a significant inhibitory effect on the seed germination of two examined weeds and on mycelial growth of the fungal strains.

This indicates that EO of $F$. vulgare could be regarded as a promising preservative in food industry in terms of having antifungal activity for food deterioration control, and may be promising alternative to synthetic herbicide.

It is recommended that other strains should be also used in order to test out their significance. However, in vivo studies must be performed to confirm this efficacy in vitro.

\section{Acknowledge}

The autors thank all the staff working in the technical floor for physical and chemical analyzes (CRAPC), Ouargla for providing the necessary research facilities.

\section{References}

Anwar F., Ali M., Hussain AI, Shahid M., Antioxidant and antimicrobial activities of essential oil and extracts of fennel (Foeniculum vulgare Mill.) seeds from Pakistan. Flavour and Fragrance Journal 24, 170-176, 2009.

Alves, M.C.S.; Medeiros Filho, S.; Manoel Neto, A.; Brito, R.C.; Araujo, R.C. Allelopathic effect of essential oils of medicinal plants in Bidens pilosa L., Rev. Bras. Pl. Med., Campinas, v.16, n.3, supl. I, p.731-736, 2014.

Asma El Ayeb, Hichem Ben Jannet, Fethia Harzallah-Skhiri, Effects of Acacia cyanophylla Lindl. extracts on seed germination and seedling growth of four crop and weed plants. Turk J Biol. 37: 305-314,2014.

Bahmani, K., Darbandi, A.I., Ramshini, et al., Agromorphological and phytochemical diversity of various Iranian fennel landraces. Ind. Crops Prod. 77, 282-294, 2015.

Chung IM, Ahn JK, Yun SJ. Assessment of allelopathic potential of barnyard grass (Echinochloa crus-galli) on rice (Oryza sativa L.) cultivars. Crop Prot 20: 921-928, 2001.

Farukh Sharopov, Abdujabbor Valiev, Prabodh Satyal et al., Cytotoxicity of the Essential Oil of Fennel (Foeniculum vulgare) from Tajikistan, Foods, 6, 73; doi:10.3390/foods6090073,2017.

Gilani SA, Fujii Y, Shinwari ZK, Adnan M, et al., Phytotoxic studies of medicinal plant species of Pakistan. Pakistan Journal of Botany 42, 986-996, 2010.

Gholami Zali, A., Ehsanzadeh, P., Szumny, A., et al., Genotypespecific response of Foeniculum vulgare grain yield and essential oil composition to proline treatment under different irrigation conditions. Ind. Crops Prod. 124, 177-185, 2018.

Kucukboyac N, Ozkan S, Adiguzel N et al. Characterisation and antimicrobial activity of Sophora alopecuroides L. var. alopecuroides alkaloid extracts. Turk J Biol 35: 379-385, 2011.

Liman R, Eren Y, Akyıl D et al. Determination of mutagenic potencies of aqueous extracts of Thermopsis turcica by Ames test. Turk J Biol 36: 85-92, 2012.

Maryam Nourimand, Sasa Mohsenzadeh, Jaime A., Allelopathic Potential of Fenn el (Foeniculum vulgare Mill.), Medicinal and Aromatic Plant Science and Biotechnology 5 (1), 54-57, 2011.

Marotti, M., Piccaglia, R., Giovanelli et al. Effects of variety and ontogenic stage on the essential oil composition and biological activity of fennel (Foeniculum vulgare Mill.). Journal of Essential OilResearch, 6(1), 57-62, 1994.

Mimica-Dukic, N.; Kujundyic, S.; Sokovic, M. Et al., Essential oil composition and antifungal activity of Foeniculum vulgare Mill. Obtained by different distillation conditions. Phytother. Res., 17, 368-371, 2003.

Mohamed Bilal Goudjil, Souad Zighmi, Djamila Hamada et al. Biological activities of essential oils extracted from Thymus capitatus (Lamiaceae), South African Journal of Botany 128: 1-9,2020.

Mustapha Abdellaoui, Eimad dine Tariq Bouhlali, Mgal Derouich, Essential oil and chemical composition of wild and cultivated fennel (Foeniculum vulgare Mill.): A comparative study, South African Journal of Botany 135 93$100,2020$.

Muckensturm, B., Foechterlen, D., Reduron, J. P., et al. Phytochemical and chemotaxonomic studies of Foeniculum vulgare. Biochemical systematics and ecology, 25(4), 353$358,1997$.

Piccaglia, R., \& Marotti, M. Characterization of some Italian types of wild fennel (Foeniculum vulgare Mill.). Journal of Agricultural and Food Chemistry, 49(1), 239-244, 2001.

Rahmani, M., [Investigation on the essential oil from the moroccan bitter fennel (Foeniculum vulgare Miller, var. Vulgare Miller thellung)]. [French]. Actes de l'Institut Agronomique et Veterinaire Hassan II 6, 5-11, 1986.

Shahat, A.A., Hammouda, F.M., Shams, K.A., et al., Comparative chemical analysis of the essential oil of wild and cultivated Fennel (Foeniculum vulgare Mill). J. Essent. Oil Bear. Plants 15, 314-319, 2012.

Singh HP., Batish DR., Kaur S., Kohli RK., Phytotoxic interference of Ageratum conyzoides with wheat (Triticum aestivum). Journal of Agronomy and Crop Science 189, 341346, 2003. 